\title{
Effect of Sprinkler and Basin Irrigation Systems on Yield and Water Use Efficiency of Canola Crop
}

\author{
Nazar Gul ${ }^{1}$, Ashifa Soomro ${ }^{2 a}$, Muhammad Munir Babar ${ }^{3}$, Liaquat Ali Jamali ${ }^{4}$, \\ Bilawal Abbasi ${ }^{2 b}$
}

RECEIVED ON 05.12.2017, ACCEPTED ON 15.09.2020

\begin{abstract}
An experiment was conducted to assess the yield potential and Water Use Efficiency (WUE) of Canola crop grown under sprinkler and basin irrigation techniques on a clay loam soil. The experiment was designed by the Principles of Randomized Complete Block Design (RCBD) with two treatments, viz. $T_{1}$ (sprinkler irrigation method) and $T_{2}$ (basin irrigation method), replicated four times. Marginal quality water with Electrical Conductivity $\left(\mathrm{EC}_{\mathrm{w}}\right)$ of $1.83 \mathrm{dS} / \mathrm{m}$ and $\mathrm{pH}$ of 8.2 was used for irrigation. The crop yield obtained under $\mathrm{T}_{1}$ and $T_{2}$ treatments were $1,407.9$ and $1,123.8 \mathrm{~kg} \mathrm{ha}^{-1}$, respectively; $20 \%$ more yield was observed under $T_{1}$ treatment. In the given order of treatments ( $T_{1}$ and $T_{2}$ ), the Canola crop used 3,605 and 4,453 $\mathrm{m}^{3} \mathrm{ha}^{-1}$ of irrigation water, hence, $19 \%$ water saving was achieved by $T_{1}$ treatment. The WUE attained under $T_{1}$ and $T_{2}$ treatments were 0.39 and $0.25 \mathrm{~kg} \mathrm{~m}^{-3}$ respectively; therefore, $35.8 \%$ WUE was enhanced under $T_{1}$ treatment. While comparing the agronomic parameters of the crop under the two procedures, all the observed parameters (plant height, number of branches plant ${ }^{-1}$, number of pods plant ${ }^{-1}$, pod length, number of seeds $\operatorname{pod}^{-1}$ and biomass plant $^{-1}$ ) were superior in case of $T_{1}$ treatment than $T_{2}$ treatment. The soil Electrical Conductivity $\left(E_{\text {se }}\right)$, Sodium Absorption Ratio (SAR), and Exchangeable Sodium Percentage (ESP) increased, and pH decreased under both the treatments, however, the maximum increase in $\mathrm{EC}_{\text {se, }}, \mathrm{SAR}$ and $\mathrm{ESP}$, and maximum decrease in pH occurred under $T_{2}$ treatment. Statistical analysis showed that the crop yield, irrigation water use, $W U E, E_{\text {se, }}$ pH, SAR, ESP, and all the agronomic parameters differed significantly $(p<0.05)$ under the two treatments.
\end{abstract}

Keywords: Sprinkler, Basin, Irrigation, Canola, Yield, Water Use Efficiency.

\section{INTRODUCTION}

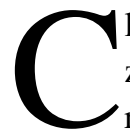
limatically, Pakistan is situated within the zones of arid to semi-arid. The precipitation rate here varies from less than $100 \mathrm{~mm}$ to more than $1,050 \mathrm{~mm}$ annually with average annual $\mathrm{ET}_{\mathrm{p}}$ (Potential Evapotranspiration) rate of about 1,778 $\mathrm{mm}$; implying that there exists a significant difference between the precipitation and $\mathrm{ET}_{\mathrm{p}}$ rates. Moreover, precipitation and $\mathrm{ET}_{\mathrm{p}}$ rates also vary temporally and spatially. Thus, for the successful growth of crops, water requirements are met through the artificial application of water.

In Pakistan, with an increase in population, industrialization, and urbanization, the stress on available water resources is increasing with time. Increase in population and changing life standards are pressing for additional food, fiber, domestic water and

\footnotetext{
${ }^{1}$ Drainage and Reclamation Institute of Pakistan (DRIP), Tando Jam. Email: nazargul43@ gmail.com

${ }^{2}$ Faculty of Agricultural Engineering, Sindh Agriculture University, Tando Jam, Sindh, Pakistan.

Email: aasoomrosau@yahoo.com, babbasi.bilawal99@gmail.com

${ }^{3}$ USPCASW, Mehran University of Engineering and Technology, Jamshoro, Sindh, Pakistan.

Email: mmunirbabar.uspcasw@ faculty.muet.edu.pk (Corresponding Author)

${ }^{4}$ Center for Social Research and Development, SIAPEP, Tando Jam, Pakistan. Email: Liaquat.jamali44@ gmail.com

This is an open access article published by Mehran University of Engineering and Technology, Jamshoro under CC BY 4.0 International License.
} 
water for environmental needs. Since the inception of the country, its population has increased manifolds; it had risen from $32.4 \mathrm{M}$ in 1948 to $168 \mathrm{M}$ in 2010 , and it is projected that it will increase to $221 \mathrm{M}$ in 2025, implying that there will be further stress on available water resources [1]. In 1951, per capita available water was $5,260 \mathrm{~m}^{3}$, whereas, presently it has declined to less than $1,000 \mathrm{~m}^{3}$, thus, placing the country in the list of water-stressed countries [2]. Under the given scenario of not having much scope for augmenting additional water resources to meet ever increasing demand for water, the gap between water supply and demand is continuously widening with time.

In Pakistan, agriculture utilizes about $93 \%$ of good quality water. The country possesses a vast network of open channel systems, through which water is delivered to agricultural lands. Water is applied to crops by inundating the agricultural fields by using conventional irrigation techniques (basin, border, and furrow). By use of these techniques, WUE varies between $30-50 \%$. Thus, a substantial amount of water is lost due to deep percolations or as surface runoff. Consequently, this results in rising of the water table, and thereby, inducing problems of water-logging and salinity [3]. The precious resource of fresh water is lost unprofitably and ultimately causing a shortage of water for potential users. Moreover, the rise of water table establishes the movement of groundwater towards the river-stream system thereby inducing the transportation of residual fertilizers, pesticides and other unwanted toxic elements towards the system, thus, deteriorating the water quality in the river-stream system for lower riparian and aquatic life.

In contrast to conventional irrigation techniques, the High-Efficiency Irrigation Systems (HEIS), such as sprinkler, bubbler, and drip irrigation systems are the potential technologies to enhance WUE. By use of these technologies, a substantial amount of water can be saved for other rational uses, as well as the associated problems as discussed above can be resolved to a better extent. Sprinkler irrigation technique, besides water saving, also offers several other benefits, such as it protects soil from erosion, avoids deep percolation, feasible for uneven topography and sloping grounds, involves lesser labor, results in healthy crop and greater yields. While comparing the benefits of sprinkler method of irrigation over border method, it had been reported that water can be saved up to $56 \%$ and thereby saving in water charges can be attained up to Rs. 7,491/ha [4]. Similarly, while comparing the sprinkler method over basin irrigation techniques, saving in water and enhancement in crop productivity can be achieved up to 50 and $40 \%$, respectively [5]. Likewise, in another investigation, while weighing rain-gun sprinkler irrigation method against basin irrigation, it is reported that WUE and crop yield can be enhanced by 30.8 and $5.64 \%$, respectively by growing sunflower crop [6]. For wheat crop, $27 \%$ higher yield was attained in addition to the water saving of $41 \%$ under rain-gun sprinkler system as compared to border irrigation technique [7]. For rice crop, $18 \%$ more yield is reported in addition to water saving of $35 \%$ when the crop is grown under the sprinkler technique in contrast to basin irrigation technique [8].

For the last 20 years, in Pakistan, cultivation of oilseed crops has been rising at a rate of $2.6 \%$ annually, whereas, consumption of oil is increasing at $9 \%$ annually. In the country, total consumption of edible oil is $2.764 \mathrm{M}$ Tons; of which $0.857 \mathrm{M}$ Tons $(31 \%)$ are produced locally, while $1.907 \mathrm{M}$ Tons (69\%) are imported annually [9]. As a result, a substantial amount of the national budget, about US\$ $800 \mathrm{M}$, is incurred on the import of the edible oil yearly [10]. Thus, there exists an immense need to increase the production of oilseed crops to bridge this gap. A large gap also exists between potential yield and existing extent of yield (per unit area) of the oilseed crops in the country. As a result of various factors, almost $74 \%$ of the yield potential is not harvested in case of these crops [11]; of these factors, irrigation technique is one of the most important factors affecting this phenomenon. Canola (Brassica Napus L.) oil is one of the major edible oil of the world; this oil possesses erucic acid lesser than $2 \%$, glucosinolates more than $30 \mu \mathrm{Mg}^{-1}$ and saturated with a smaller amount of fats $(5-8 \%)$ in comparison to other edible oils [12]. Since the Canola crop has low erucic acid contents and high yielding capacity [13]; therefore, in 1995, this crop was introduced into the country.

The objective of the present research study is to assess the effect of sprinkler and basin irrigation techniques on Canola crop yield, its water use, and WUE. Additionally, since, marginal quality water is used for ol. 40, No. 2, April 2021 [p-ISSN: 0254-7821, e-ISSN: 2413-7219] 
irrigation purpose, therefore, any change in soil chemical properties (soil salinity) is also assessed by analyzing the soil $\mathrm{EC}_{\mathrm{se}}, \mathrm{pH}, \mathrm{SAR}$, and $\mathrm{ESP}$.

\section{MATERIALS AND METHOD}

\subsection{Experimental Site and Design}

The study was conducted in the experimental field of the Drainage and Reclamation Institute of Pakistan (DRIP), Tando Jam, Sindh, Pakistan, during 20132014. The Institute is located at $25^{\circ} 25^{\prime} 10.6^{\prime \prime}$ North latitude and 68 31' 35.2" East longitude and an average altitude of $12.8 \mathrm{~m}$ above the mean sea level. The experiment was set up as per the principles of RCBD with two treatments, viz. $\mathrm{T}_{1}$ (sprinkler irrigation method) and $\mathrm{T}_{2}$ (basin irrigation method) and four replications. For each treatment and replication, plot size was kept as identical $(36.9 \times 27.4 \mathrm{~m})$. The soil texture of the experimental site is clay loam. Throughout the cropping period, for irrigation purpose, marginal quality water with $\mathrm{EC}_{\mathrm{w}}=$ $1.83 \mathrm{dS} / \mathrm{m}$ and $\mathrm{pH}=8.2$ was used.

\subsection{Land Preparation, Seed Planting, and Fertilization}

At the outset, the land was thoroughly plowed twice using the disc-harrow and cultivator type of plows. A soaking dose of water was then applied to all the experimental plots. When the field reached the working condition, once again the entire area was plowed by using the cultivator type of plow, and after that, all plots were leveled conventionally. A local variety of Canola seed, known as Surhan, was sown by drilling method using a single colter hand drill. The spacing from inter-row and intra-row was maintained at 30.5 and $20 \mathrm{~cm}$, respectively. As per the recommendations made in [14], fertilizer (NPK) dose was applied at the rate of $90-60-0 \mathrm{~kg} \mathrm{ha}^{-1}$. The nitrogen was applied in the form of Urea, and phosphorous in the form of Di-Ammonium Phosphate. The entire dose of phosphorus was used all at once during the land preparation phase; while, nitrogen dose was split into three equal parts, and a part of that was applied after each irrigation exercise.

\subsection{Application of Irrigation Water}

Altogether three irrigation exercises were done. Following the recommendations made in [15], the first irrigation water was applied after 21 days of crop sowing (early vegetative stage), while second irrigation was exercised after 56 days of crop sowing (flowering stage) and the third irrigation was exercised after 93 days of crop sowing (seed formation stage). At each stage, the depth of water required for irrigation purpose was computed by using the formulation given in equation (1):

$\mathrm{R}=\frac{\left(\mathrm{F}_{\mathrm{c}}-\mathrm{M}_{\mathrm{c}}\right)}{100} \times \mathrm{B} \times \mathrm{D}$

where, $\mathrm{R}$ is the required depth of irrigation water $(\mathrm{cm})$, $\mathrm{F}_{\mathrm{C}}$ represents field capacity $(\mathrm{g} / \mathrm{g}), \mathrm{M}_{\mathrm{C}}$ denotes soil moisture content (g/g), B signifies the dry bulk density of the soil $\left(\mathrm{g} / \mathrm{cm}^{3}\right)$ and D stands for root depth of the crop at the time of irrigation $(\mathrm{cm})$.

Veihmeyer and Hendricksen [16] method was used for determination of the field capacity. Just one day before the application of irrigation water, the available moisture content in root zone depth was determined by gravimetric technique. The root zone depth is calculated by its growth rate $(8 \mathrm{~mm} /$ day $)$ as reported by [17]. Thus, for first, second and third irrigation, soil moisture content was determined from 0-12, 0-40, and 0-70 cm, respectively. The dry bulk density was determined by core method [18].

\subsection{Yield Response and WUE}

The yield of the Canola crop from each replication was measured in kilograms and averaged, then converted into units of $\mathrm{kg} \mathrm{ha}^{-1}$. The yield response (increase in yield) in percent is calculated as per the equation (2).

Increase in yield $(\%)=\frac{\left(Y_{1}-Y_{2}\right)}{Y_{1}} \times 100$

where, $\mathrm{Y}_{1}$ is the total yield of Canola crop obtained under sprinkler irrigation system $\left(\mathrm{kg} \mathrm{ha}^{-1}\right)$ and $\mathrm{Y}_{2}$ denotes the total produce of the crop obtained under basin irrigation system $\left(\mathrm{kg} \mathrm{ha}^{-1}\right)$

The WUE for the Canola crop grown under sprinkler and basin irrigation systems is calculated by using the equation (3): 
WUE $=\frac{Y}{R} \times 100$

where, WUE is the Water Use Efficiency $\left(\mathrm{kg} \mathrm{m}^{-3}\right), \mathrm{Y}$ denotes yield of the Canola crop $\left(\mathrm{kg} \mathrm{ha}^{-1}\right)$ and $\mathrm{R}$ symbolizes for the total quantity of water consumed by Canola crop for its production $\left(\mathrm{m}^{3} \mathrm{ha}^{-1}\right)$.

Since the water used for irrigation purpose was of marginal quality with $\mathrm{EC}_{\mathrm{w}}=1.83 \mathrm{dS} / \mathrm{m}$ and $\mathrm{pH}=8.2$, therefore, to assess any change in soil salinity, soil samples were collected before the sowing and after the harvest of the crop for the soil salinity status analysis. The soil samples were collected at the depths of 0-15, $15-30,30-45$ and $45-60 \mathrm{~cm}$. The $\mathrm{pH}$ and $\mathrm{EC}_{\mathrm{se}}$ were determined by $1: 2$ soil-water-extract method [19] with the help of digital $\mathrm{pH}$ and $\mathrm{EC}$ meter, respectively.

Soluble $\mathrm{Ca}^{2+}$ and $\mathrm{Mg}^{2+}$ were determined by EDTA titration method, while $\mathrm{Na}^{+}$was analyzed by the EELFlame Photometer [20]. The formulations for computation of SAR and ESP are presented in equations (4-5), respectively:

$\mathrm{SAR}=\frac{\mathrm{Na}^{+}}{\sqrt{\frac{\mathrm{Ca}^{2+}+\mathrm{Mg}^{2+}}{2}}}$

$\mathrm{ESP}=\frac{100(-0.0126 \times 0.01475 \times \mathrm{SAR})}{1+(-0.0126+0.01475 \times \mathrm{SAR})}$

\subsection{Performance of Sprinkler System}

The sprinkler system installed at the DRIP is a fixed rotary system, which covered entire experimental blocks. In total, there are 18 sprinkler heads, each

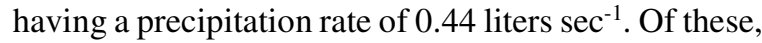
eight sprinklers are designed to cover half circle, while, rest of them are designed to cover the full circle. Before execution of the experiment, performance of the sprinkler system was assessed; the performance parameters included, assessment of Uniformity Coefficient (CU) and Distribution Uniformity (DU). The CU is determined by the Christiansen formula [21, 22]; and the DU is computed by the equation proposed in [23]; the formulations for CU and DU are reproduced in equation (6):

$\mathrm{CU}=\left[1-\frac{\sum_{\mathrm{i}=1}^{\mathrm{n}}\left|\mathrm{x}_{\mathrm{i}}-\overline{\mathrm{x}}\right|}{\mathrm{n} \times \overline{\mathrm{x}}}\right]$ where, $\mathrm{CU}$ is the uniformity coefficient in $\%, \mathrm{X}$ is denotes the mean water depth collected in all catchcans, $\mathrm{n}$ is stands for the total number of catch-cans and $\mathrm{X}_{\mathrm{i}}$ is the water depth collected in an individual catchcan in Equation (7).

$\mathrm{DU}_{\mathrm{lq}}=\frac{\overline{\mathrm{v}}_{\mathrm{lq}}}{\overline{\mathrm{V}}}$

where, $\mathrm{DU}_{\mathrm{lq}}$ is the $\mathrm{DU}$ in the lowest quarter in $\%, \overline{\mathrm{V}}_{\mathrm{lq}}$ denotes the mean of the lowest quarter volume (or depth) of water collected in the cans, $\bar{V}$ is stands for the average volume (or depth) of water collected by all catch-cans.

The performance test was carried out for each sprinkler head. In total, forty-eight catch-cans were used covering an area of $144 \mathrm{~m}^{2}$ (Fig. 1). The spacing between catch-cans was maintained as per recommendations made in [24]. The diameter and height of each catch-can were 76 and $80 \mathrm{~mm}$, respectively. All sprinkler heads were operated for half an hour, and the volume of water collected in each catch-can was measured.

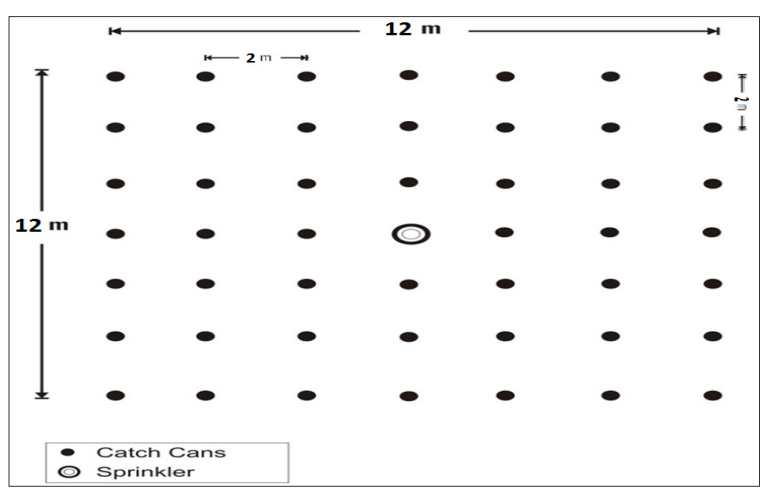

Fig. 1: Layout of Catch-Cans around a Sprinkler Head

\subsection{Statistical Analysis}

All the collected data were statistically analyzed using Statistic software (Version 8.1).

\section{RESULTS AND DISCUSSION}

\subsection{Performance of Sprinkler Irrigation System}

The CU and DU of the present sprinkler system were determined under an operating pressure head of $28 \mathrm{psi}$. 
According to [22], a sprinkler irrigation system is categorized as satisfactory if it's CU $>=84 \%$ and DU varies between $80-85 \%$ [25]. The $\mathrm{CU}$ and DU, for the present system, are estimated at 86.9 and $81.6 \%$; thus the performance of the system is rated as satisfactory.

\subsection{Irrigation Water Use}

Fig. 2 presents the volume of irrigation water used for growing Canola crop under the two irrigation systems. The crop used 3,605 and 4,453 $\mathrm{m}^{3} \mathrm{ha}^{-1}$ of irrigation water under $T_{1}$ and $T_{2}$ treatments, respectively. The higher amount of irrigation water was used by $T_{2}$ treatment than its counterpart. The amount of irrigation water saved under $\mathrm{T}_{1}$ treatment is $19 \%$ as compared to $T_{2}$ treatment; this is because lighter irrigation is exercised under the sprinkler system; hence, runoff and deep percolation losses are negligible here. Thus, field application efficiency under $T_{1}$ treatment is higher than the $T_{2}$ treatment. In contrast, under basin irrigation system, the entire field is flooded with water. Thus, there are more percolation and runoff losses; hence, field application efficiency under $\mathrm{T}_{2}$ treatment is inferior to its counterpart. These results are also supported by [5, 6]. Statistically, the water used by the crop under $T_{1}$ and $T_{2}$ treatments were significantly different $(\mathrm{P}<0.05)$.

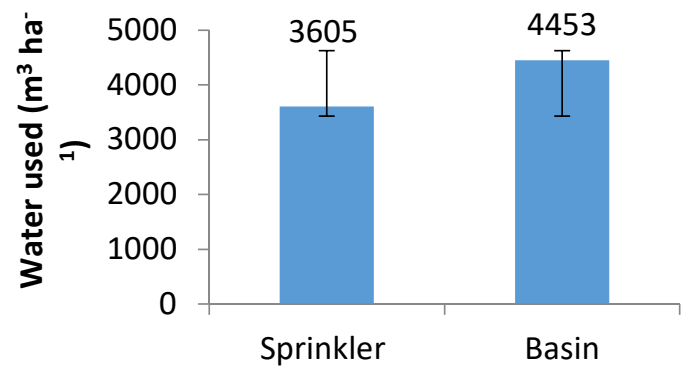

Fig. 2: Volume of Water used for $T_{1}$ and $T_{2}$ treatments

\subsection{Crop Yield}

The yield of the crop under the two treatments is presented in Fig. 3. The yield attained under $\mathrm{T}_{1}$, and $\mathrm{T}_{2}$ treatments are 1,407.9 and 1,123.8 $\mathrm{kg} \mathrm{ha}^{-1}$. Noticeably, a higher yield is attained under $T_{1}$ treatment than in $T_{2}$ treatment. The increase in yield under $T_{1}$ treatment is attributed to the lighter dose of irrigation waters, relatively uniform distribution of irrigation waters and better aeration in the root-zone profile of the crop. Under $T_{1}$ treatment, the crop yield increased by 20.17\% in comparison to its counterpart. Similar results are also reported by [6-8]. Statistically, the crop yield attained under $T_{1}$, and $T_{2}$ treatments were significantly different $(\mathrm{P}<0.05)$.

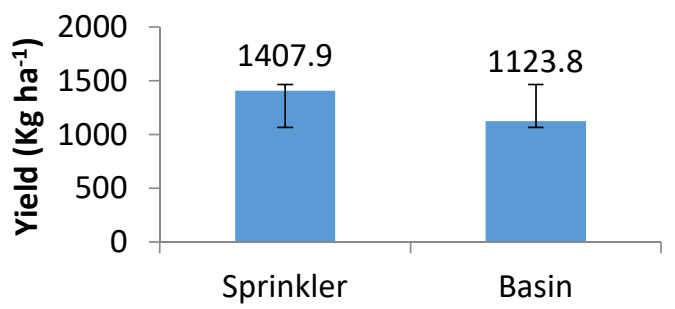

Fig. 3: Yield of crop obtained under $T_{1}$ And $T_{2}$ treatments

\subsection{Water Use Efficiency}

The WUE attained under $T_{1}$, and $T_{2}$ treatments for the growing of Canola crop is 0.39 , and $0.252 \mathrm{~kg}$ $\mathrm{m}^{-3}$, respectively as presented in Fig. 4. Obviously, the water use efficiency attained under sprinkler irrigation system is higher than its counterpart. The WUE attained under $\mathrm{T}_{1}$ treatment is higher by $35.38 \%$ over the $T_{2}$ treatment. The reason for higher WUE in $T_{1}$ treatment is because of the lesser consumption of irrigation water and higher yield attained. Similar findings were also reported by [5]. Statistically, the WUEs attained under $T_{1}$, and $T_{2}$ treatments were significantly different $(\mathrm{P}<0.05)$.

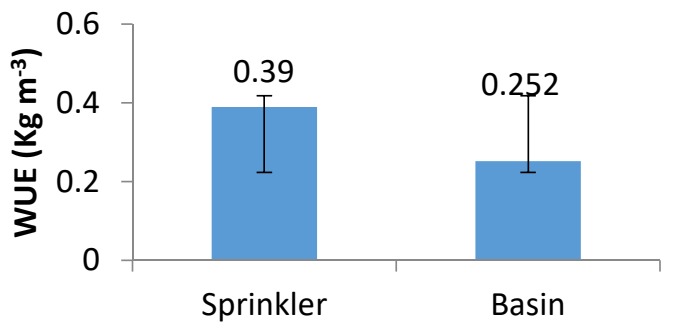

Fig. 4: WUE attained under $T_{1}$ and $T_{2}$ Treatments

\subsection{Agronomic Parameters}

During the study, agronomic parameters of the crop, such as; plant height, number of branches plant ${ }^{-1}$, number of pods plant ${ }^{-1}$, pod length, number of seeds $\operatorname{pod}^{-1}$ and plant biomass, were also studied. The data on these parameters are presented in Table 1. From the 
Table 1, it can be seen that for all the agronomic parameters, higher values are attained under $T_{1}$ treatment as compared to its counterpart. Superior values of the agronomic parameters under $T_{1}$ treatment were attributed to the lighter dose of irrigation waters, relatively uniform distribution of irrigation waters and better aeration in the root-zone profile of the crop. Statistically, all the agronomic parameters attained under $\mathrm{T}_{1}$, and $\mathrm{T}_{2}$ treatments differ significantly $(\mathrm{P}<$ $0.05)$.

\begin{tabular}{|c|c|c|}
\hline \multicolumn{3}{|c|}{ Table 1: Agronomic Parameters for Canola Crop } \\
\hline \multirow{2}{*}{ Agronomical Parameters } & \multicolumn{2}{|c|}{ Irrigation Methods } \\
\cline { 2 - 3 } & Sprinkler & Basin \\
\hline Plant height $(\mathrm{cm})^{-1}$ & 116 & 111 \\
\hline Number of branches plant $^{-1}$ & 12 & 09 \\
\hline Number of pods plant $^{-1}$ & 69 & 51 \\
\hline Pod length $(\mathrm{cm})^{-1}$ Number of seeds pod $^{-1}$ & 2.6 & 2.4 \\
\hline Biomass plant $^{-1}(\mathrm{~g})$ & 25 & 21 \\
\hline & 0.47 & 0.41 \\
\hline
\end{tabular}

\subsection{Soil Chemical Properties}

Soil $\left(\mathbf{E C}_{\mathrm{se}}\right)$ : In $\mathrm{T}_{1}$ and $\mathrm{T}_{2}$ treatments, the $\mathrm{EC}_{\mathrm{se}}$ of the soil samples obtained before sowing of the crop was estimated at 1.63 and $1.48 \mathrm{dS} \mathrm{m}^{-1}$, respectively; likewise, the $\mathrm{EC}_{\mathrm{se}}$ of the soil samples acquired after harvest of the crop was1.81 and $1.69 \mathrm{dS} \mathrm{m}^{-1}$, respectively. The $\mathrm{EC}_{\mathrm{se}}$ increased by 0.18 and $0.21 \mathrm{dS}$ $\mathrm{m}^{-1}$ under the $\mathrm{T}_{1}$ and $\mathrm{T}_{2}$ treatments, respectively. The maximum increase in $\mathrm{EC}_{\mathrm{se}}$ occurred under $\mathrm{T}_{2}$ treatment; this is because a larger amount of irrigation water was used under $T_{2}$ treatment, which in consequence resulted in accumulation of more salts in the soil profile. The magnitude of $\mathrm{EC}_{\mathrm{se}}$ of the soil samples obtained after harvest of the crop is not comparable to $\mathrm{EC}_{\mathrm{w}}$; this could obviously be attributed to the following reasons: (i) the soil of the experimental plots is of good quality $\left(\mathrm{EC}_{\mathrm{se}}<4 \mathrm{dS} / \mathrm{m}\right)$, (ii) some amount of salts is also taken-up by plant body [26-29], (iii) the concentration of salts available in the marginal quality water is diluted/distributed among a bigger mass of soil, and (iv) the mass of water that is added for irrigation purpose is much lesser than the bulk mass of the soil that supports the plant life. It may also be intruded that if marginal quality water is used for irrigation purpose for a longer period without the addition of leaching factor, in that case, the ECse may reach to an equivalent or higher state of ECw.Statistically, the $\mathrm{EC}_{\mathrm{se}}$ estimated under $\mathrm{T}_{1}$ and $\mathrm{T}_{2}$ treatments differ significantly $(\mathrm{P}<0.05)$.
Soil pH: In $\mathrm{T}_{1}$ and $\mathrm{T}_{2}$ treatments, the $\mathrm{pH}$ value of soil samples before sowing of thecropwere7.73 and 7.70, respectively. Similarly, the $\mathrm{pH}$ values for soil samples acquired after harvest of the crop were obtained as 7.71 and 7.67. The maximum decrease in $\mathrm{pH}$ occurred under $\mathrm{T}_{2}$ treatment; this is because the higher quantity of irrigation water was used under this treatment. The fertilizers used under $\mathrm{T}_{2}$ treatment had more opportunity to be dissolved, and thereby it induced a decrease in soil $\mathrm{pH}$. These findings also confirmed by the research results obtained by $[30,31]$. According to them, due to the application of synthetic fertilizers, nitrification and acidification processes initiate and also due to the release of $\mathrm{H}^{+}$by plant roots, the $\mathrm{pH}$ value of soil decreases. The values of soil $\mathrm{pH}$, even after the harvest of crop, is furthermore reduced due to leaching impacts in upper soil layers and dissolved carbonic and organic acids, which remove metal cations (e.g., $\mathrm{Ca}^{++}, \mathrm{K}^{+}, \mathrm{Mg}^{++}$) and replace them with $\mathrm{H}^{+}$ions [32]. Moreover, plant growth and nutrient uptake also result in some localized acidification (decrease in soil $\mathrm{pH}$ ) around plant roots through the exudation of acids from the roots [33]. Statistically, the $\mathrm{pH}$ value obtained under $\mathrm{T}_{1}$ and $\mathrm{T}_{2}$ treatments differed significantly $(\mathrm{P}<0.05)$.

Soil SAR: In $\mathrm{T}_{1}$ and $\mathrm{T}_{2}$ treatments, the SAR of soil samples obtained before sowing was 2.63 and 2.32 and after harvest of the crop were 2.73 and 2.55, respectively. The soil SAR increased by 0.10 and 0.23 under $\mathrm{T}_{1}$ and $\mathrm{T}_{2}$ treatments, respectively. The maximum increase in SAR occurred under $T_{2}$ treatment. This increase in SAR is attributed to the use of marginal quality irrigation water and also because of more amount of irrigation water used under this intervention. The permissible limit for SAR is less than 7.0 [34]. Statistically, the SAR value obtained under $\mathrm{T}_{1}$ and $\mathrm{T}_{2}$ treatments differ significantly $(\mathrm{P}<$ $0.05)$.

Soil ESP: In $T_{1}$ and $T_{2}$ treatments, the ESP of soil samples obtained before sowing was 2.57 and 2.12 and after harvest of the crop were 2.70 and 2.44, respectively. The soil ESP increased by 0.13 and 0.32 under $\mathrm{T}_{1}$ and $\mathrm{T}_{2}$ treatments, respectively. The maximum increase in ESP occurred under $T_{2}$ treatment. This increase in ESP may be attributed to the use of marginal quality irrigation water and also because of more utilization of irrigation water under 
this intervention. The ESP values under both the treatments remained within the safe limit (i.e. < 15) [35]. Statistically, the ESP values obtained under $T_{1}$ and $\mathrm{T}_{2}$ treatments differ significantly $(\mathrm{P}<0.05)$.

\section{CONCLUSION}

From the study, it can be concluded that the methods of irrigation (sprinkler and basin) have a significant effect on irrigation water use, crop yield, WUE and agronomic parameters of the Canola crop. Sprinkler irrigation technique can successfully grow the Canola crop with a considerable increase $(20.17 \%)$ in yield and substantial improvement in WUE (35.38\%). The amount of irrigation water saved $(19 \%)$ by sprinkler irrigation technique in comparison to its counterpart is also sizeable. Since marginal quality irrigation water is used for irrigation purpose, therefore, soil chemical properties (soil salinity parameters) changed under both types of irrigation interventions. Moreover, since, a higher amount of irrigation water is used under basin irrigation system, therefore, more increase in soil salinity parameters occurred under this system, implying that in case of using marginal quality water for supplementing the water requirements of crops under basin method of irrigation in clay loam soil texture, the soil is more venerable towards salinity development.

\section{ACKNOWLEDGMENT}

The authors acknowledge the Director Incharge and the Field Staff of Drainage and Reclamation Institute of Pakistan, Tando Jam, Pakistan, for their constant cooperation during the study period.

\section{REFERENCES}

1. Qureshi A.L., Lashari B.K., Kori S.M., Lashari G.A., "Hydro-Salinity Behavior of Shallow Groundwater Aquifer Underlain by Salty Groundwater in Sindh Pakistan", Proceedings of the $15^{\text {th }}$ International Water Technology Conference, Alexandria, Egypt, 2011.

2. Raheel M., "Pakistan's Biggest Challenge: The Impending Water Crisis", American Pakistan Foundation, 2013.

3. Ishfaq M., "Water New Technology", Global Water Institute, Lahore, Pakistan, 2002.
4. Zongli L., Wenju Z., Wei S., Yanwei F., "Application Prospect of Sprinkler Irrigation Technology in Water-Short Areas of Northern China", Transactions of the Chinese Society of Agricultural Engineering, Vol. 28, No. 6, pp. 1-6, 2012.

5. Adeeb A.M., Abdel W.D.M., "Comparison of Sprinkler and Surface Irrigation Methods for Sugarcane Production in Kenana Sugar Company, Sudan", Gezira Journal of Agricultural Sciences, Vol. 7, No. 2, pp. 162-170, 2009.

6. Rana M.A., Arshad M., Masud J., "Effect of Basin, Furrow and Rain Gun Sprinkler Irrigation Systems on Irrigation Efficiencies, NitrateNitrogen Leaching, and Yield of Sunflower", Pakistan Journal of Water Resources, Vol. 10, No. 2, pp. 1-7, 2006.

7. Anwar S., Khaliq A., Nabi G., Zafar M., "Use of Rain Gun Sprinkler System for Enhancement of Wheat Production", Pakistan Journal of Life Society Sciences, Vol. 2, No. 2, pp. 174-177, 2004.

8. Kahlown M.A., Kemper W.D., "Seepage Losses as Affected by Condition and Composition of Channel Banks", Agricultural Water Management, Vol. 65, No. 2, pp. 145-153, 2004.

9. Anonymous, "Economic Survey of Pakistan", Ministry of Finance, pp. 11-16, Government of Pakistan, 2006.

10. GoP, "Agricultural Statistics of Pakistan", The Government of Pakistan, Ministry of Food, Agriculture, and Livestock, Food and Agriculture Division (Economic Advisory Wing), Islamabad, 2002.

11. Amjad M., "Status Paper - Oilseed Crops of Pakistan”, Plant Sciences Division, Pakistan Agricultural Research Council, pp. 40, Islamabad, Pakistan, 2014.

12. Raymer P.L., "Canola: An Emerging Oilseed Crop", Trends in New Crops and New Uses, Janick J., and Whipkey A., (Editors), pp. 122-126, ASHS Press, Alexandria, VA, 2002.

13. Chaudhry S.U., Hussain M., Iqbal J., "Effect of Different Herbicides on Weed Control and Yield of Canola (Brassica Napus L.)", Journal of Agricultural Research, Vol. 49, No. 4, pp. 483490, 2011. 
14. Cheema M.A., Malik M.A., Hussain A., Shah S.H., Basra S.M.A., "Effects of Time and Rate of Nitrogen and Phosphorus Application on the Growth and the Seed and Oil Yields of Canola", Journal of Agronomy and Crop Science, Vol. 186, No 2, pp. 103-110, 2001.

15. Tahir M., Ali A., Nadeem M.A., Tanveer A., Sabir Q.M., "Performance of Canola (Brassica Napus L.) Under Different Irrigation Levels", Pakistan Journal of Botany, Vol. 39, No. 3, pp. 739-746, 2007.

16. Veihmeyer, F.J., and Hendrickson, A.H., "The Moisture Equivalent as a Measure of the Field Capacity of Soils", Soil Science, Vol. 32, pp. 181193, 1931.

17. Edwards, "Canola Growth and Development", New South Wales (NSW), Government, Department of Primary Industries, Profitable Sustainable Cropping (PRO CORP) Canola Growth and Development, 2011.

18. McIntyre D.S., Loveday J., "Bulk Density", in Loveday J., (Editor), Methods of Analysis for Irrigated Soils, Commonwealth Agricultural Bureau of Technical Communication, No 54, Farnham Royal, England, 1974.

19. Rowell D.L., "The Preparation of Saturation Extracts and the Analysis of Soil Salinity and Sodicity", Soil Science Methods and Applications, Rowell D.L., (Editor), Longman Group, UK, 1994.

20. Fresenius W., Quentin K.E., Schneidler W., "Water Analysis a Practical Guide to PhysicChemical, Chemical and Microbiological Water Examination and Quality Assurance", SpringerVerlay, Berlin, 1988.

21. Christiansen J.E., "Irrigation by Sprinkling", California Agriculture Experiment Station Bulletin, No. 670, 1942.

22. Keller J., Bliesner R.D., "Sprinkler and Trickle Irrigation", Van Nostrand Reinhold, Vol. 3, No. 5, pp. 86-96, New York, 1990.

23. Ascough G.W., Kiker G.A., "The Effect of Irrigation Uniformity on Irrigation Water Requirements", Water Resource Commission, South Africa, pp. 235-241, 2002.

24. Merkley G.P., Allen R.G., "Sprinkle and Trickle Irrigation Lecture Notes, Utah State University", USA, pp. 10-43, 2004.
25. Huck M., "Does Your Irrigation System Make the Grade?", Turf Grass Information Center, pp. 1-5, USA, 2000.

26. Kim H., Jeong H., Jeon J., Bae S., "Effects of Irrigation with Saline Water on Crop Growth and Yield in Greenhouse Cultivation", Journal of Water, Vol. 8, No. 127, pp. 1-9, 2016.

27. Sheldon A., Menzies N.W., So H.B., Dalal R., "The Effect of Salinity on Plant Available Water", Proceedings of the 3rd Australian New Zealand Soils Conference on Super Soil, University of Sydney, Australia. Published on CDROM, 5-9 December 2004.

28. Taiz L., Zeiger E., "Plant Physiology", 3rd Edition, Publisher Sinauer, pp. 690, Sunderland, UK, 2002.

29. Munns R., Husain S., Rivelli A.R., Richard A.J, Condon A.G., Megan P.L., Evans S.L., Schachtman D.P., Hare R.A., "Avenues for Increasing Salt Tolerance of Crops, and the Role of Physiologically Based Selection Traits", Plant Soil, Volume 247, pp. 93-105, 2002.

30. Czarnecki, S., and During R.A., "Influence of Long-Term Mineral Fertilization on Metal Contents and Properties of Soil Samples Taken from Different Locations in Hesse, Germany", Journal of Soil, Vol. 1, pp. 23-33, 2015.

31. Liang Q., Chen H., Gong Y., Fan M., Yang H., Lal R., Kuzyakov Y., "Effects of 15 Years of Manure and Inorganic Fertilizers on Soil Organic Carbon Fractions in a Wheat-Maize System in the North China Plain", Nutrient Cycling in Agroecosystem, Vol. 92, pp. 21-33, 2012.

32. Goulding, K.W.T., "Soil Acidification and the Importance of Liming Agricultural Soils with Particular Reference to the United Kingdom", Journal of Soil Use and Management, Vol. 32, No. 3, pp. 390-399, 2016.

33. Hinsinger P., Plassard C., Tang C., Jaillard B., "Origins of Root-Mediated $\mathrm{pH}$ Changes in the Rhizosphere and Their Responses to Environmental Constraints: A Review", Plant and Soil, Vol. 248, pp. 43-59, 2003.

34. USDA, "Diagnosis and Improvement of Saline and Alkali Soil", Agriculture Hand Book No. 60, US Soil Salinity Laboratory Staff, United States Department of Agriculture, pp. 108 \& 121, 1969. 
35. Horneck D.S., Ellsworth J.W., Hopkins B.G., Sullivan D.M., Stevens R.G., "Managing SaltAffected Soils for Crop Production”, PNW 601-E. Oregon State University, University of Idaho, Washington State University, 2007. 